\title{
Entrepreneurship and Economic Development
}

\author{
Seerat ${ }^{1}$ \\ ${ }^{1}$ (Resource Person at PGGCG, Sector-11, Chandigarh)
}

\begin{abstract}
The world is turning its eyes towards India as India is ready to start a new phase in its journey towards becoming an economic powerhouse. The stage is all set for India as it is receiving the necessary initiatives from the Modi government. The backbone of every economy is its manufacturing sector, which helps in the generation of employment, productivity, and growth. The recent initiatives taken by the government would help new entrepreneurs to grow and flourish. Make in India, Digital India, Skill India are some of the major programs started by the government that would help new entrepreneurs to grab the opportunities presented to them. Entrepreneurs are known for creating new businesses and the ones' who create new employment opportunities for the society at large. This paper is an attempt to study the opportunities that are available to the entrepreneurs in India. The paper presents a brief history of entrepreneurship, its growth in India and the new opportunities that are available in the wake of digital economy initiatives by the government. The paper also discusses briefly about the challenges faced by new entrepreneurs in India. China is losing its cost advantage due to rising wages and increasing cost of production. In such a scenario India is emerging as a global manufacturing powerhouse. In this economically conducive environment Indian entrepreneurs are ready to make their mark globally. The only prerequisite is proper support by the government, which the government is ready to provide through various initiatives. This would lead to the economic growth of the country by providing proper environment to entrepreneurs to tap new opportunities.
\end{abstract}

Keywords- entrepreneurship, digital India, entrepreneur, start-up India

\section{INTRODUCTION}

Entrepreneurship can play a vibrant role in the economic development of India. India is a country that has an incredible demographic dividend to its credit. To tap this demographic dividend the Prime Minister, Sri Narendra Modi has introduced "Start up, Stand up India" program which inspires young entrepreneurs to come up with innovative ideas to start up their own units. The vision of the government is to transform the young population from job seekers to job creators. This initiative is taken by the government to create more job opportunities in the country. The program aims to promote bank financing for start-ups and offers enticements to boost entrepreneurship and job creation in the country. Entrepreneurship can play a significant role in an economy characterized by copious labor supply and unemployment. To utilize this prolific labour supply and to exterminate unemployment it becomes imperative for India to encourage young entrepreneurs to come up with ground-breaking ideas to start up their own units. This will help in generation of more jobs in the country which will help to overcome the problem of unemployment in the country and it will also lead to the economic growth of the country. Before deliberating further on the concept of entrepreneurship let us understand the concept by looking at the definitions of entrepreneurship.

\section{ORIGIN AND EVOLUTION OF THE CONCEPT OF ENTREPRENEURSHIP}

The word entrepreneur " is derived from the French verb "enterprendre". It means "to undertake". In simple words, entrepreneurship is considered as an art of becoming an entrepreneur, which means the entrepreneur would assume the risk of starting up a business unit based on his /her unique and innovative idea. The idea may be a new one or an old idea which is presented in a new way.

Here are some definitions of the term given by eminent personalities as indicated below- 


\section{- Joseph Schumpeter}

"The entrepreneur in an advanced economy is an individual who introduce something new in the economya method of production not yet tested by experience in the branch of manufacturing, a product with which consumers are not yet familiar, a new source of raw material or of new markets and the like"

\section{- Peter F. Drucke}

"An entrepreneur is the one who always searches for change, responds to it, and exploits it as an opportunity. Innovation is the specific tool of entrepreneurs, the means by which they exploit changes as an opportunity for a different business or different service"

\section{- Richard Cantillon}

"A person who pays certain price for a product to resell it at an uncertain price thereby making decision about obtaining and using resources while assuming the risk of enterprise"

\section{- Adam Smith}

"Entrepreneur is an employer, master, merchant but explicitly considered as a capitalist"

From the above definitions it is clear that entrepreneurs are individuals with a different and innovative mindset. They assume the risk of investing in their unique ideas which not only help in their own growth but the growth of the nation also. Entrepreneurs create new job opportunities in the country which lifts the economy as a whole.

In developing countries like India there is an enormous scope to tap new opportunities as huge markets are left untapped. This is an incentive for young entrepreneurs to come up with ideas to tap this potential. This will also reduce the burden on the government as the government cannot provide job opportunities to each and every individual in the country. An alternate source of job creation is the need of the hour in case of India. Entrepreneurship is the source which can be used to achieve the objective of job creation and economic development of the nation.

\section{ENTREPRENEURSHIP IN INDIA}

The concept of entrepreneurship is not new in India. India was one of the major trade hubs in the world. Indians were specialists in smelting of metals. Kanishka Empire in the 1st century started nurturing Indian entrepreneurs and traders.Around 1600 A.D. India had established trade relations with Europe and later expanded these trade relations with Portuguese and English.

Entrepreneurship is a part of India's tradition. With the rise in Knowledge intensive services, the salience of entrepreneurship has intensified in recent times. India is on its way of becoming a global powerhouse. China is losing its cost advantage due to rising wages and increasing cost of production. In such a scenario India is emerging as a global manufacturing powerhouse. In this economically conducive environment Indian entrepreneurs are ready to make their mark globally.

To support the entrepreneurs The Government has taken critical steps to empower the youth of India to tap this emerging opportunity. To impart the required skills for tapping this opportunity, The Government has initiated "Skill India" Campaign. To remove the digital divide between the urban and rural areas The Government has initiated Digital India" Campaign, which will help the entrepreneurs to tap the rural markets as well and which would also provide a platform to the rural youth to showcase their talent to the world on a digital platform.

"Make in India" Campaign led by Modi Government aims at getting new business opportunities in the country. The concept of "smart Cities" is another major project of The Government that would give a boost to entrepreneurship in India and ultimately help the economy as a whole to achieve its growth targets. 


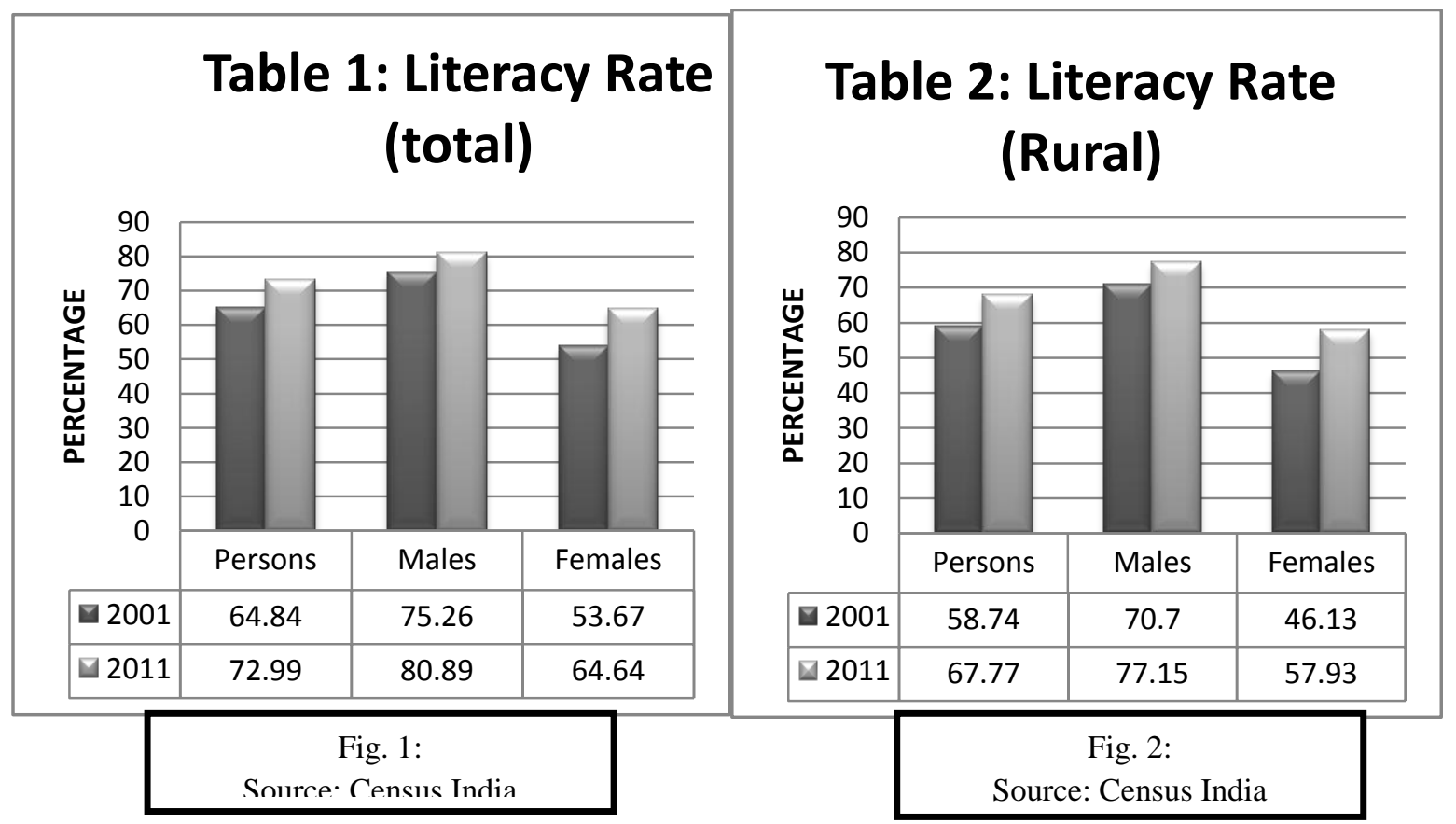

India's young age structure offers a potential demographic dividend for growth, but this potential will be realized only if the extent and quality of education and skill development among new entrants to the workforce is greatly enhanced.

The first graph shows the overall literacy rate in India which shows a significant increase from the year 2001 to 2011. The second graph represents the literacy rate specifically in rural areas and it is evident from the graph that literacy rate among men as well as women has increased to significant levels.

Without quality education, young entrepreneurs cannot be nurtured. This is the reason that has forced government to impart quality education and required skills so as to encourage young entrepreneurs to come up with their unique and innovative Ideas. The Government has the vision of transforming its young population from job seekers to job creators. This is the reason due to which entrepreneurship in India is gaining the required attention.

\begin{tabular}{|l|l|l|}
\hline Country/area & $\begin{array}{l}\text { Confidence in domestic } \\
\text { economic direction }\end{array}$ & $\begin{array}{l}\text { Confidence in global } \\
\text { economic direction }\end{array}$ \\
\hline China & $95 \%$ & $89 \%$ \\
\hline India & $95 \%$ & $89 \%$ \\
\hline Middle East/North Africa & $90 \%$ & $82 \%$ \\
\hline Sub Saharan Africa & $81 \%$ & $84 \%$ \\
\hline Germany & $83 \%$ & $68 \%$ \\
\hline UK & $76 \%$ & $51 \%$ \\
\hline US & $70 \%$ & $58 \%$ \\
\hline Canada & $68 \%$ & $55 \%$ \\
\hline Mexico & $66 \%$ & $73 \%$ \\
\hline Brazil & $54 \%$ & $80 \%$ \\
\hline France & $52 \%$ & $56 \%$ \\
\hline Australia & $51 \%$ & $37 \%$ \\
\hline Japan & $49 \%$ & $44 \%$ \\
\hline
\end{tabular}

Fig. 3: Economic Confidence (Source: Ernst \& Young Survey 2015) 
The above figure shows that China, India, the Middle East/ North Africa and Sub Saharan Africa are characterized by overwhelming confidence in both their own markets and the global economy. Meanwhile, France, Australia, and Japan have the lowest confidence levels. This shows that India is all set to tap the opportunities in the domestic as well as global markets and this is the right time to give boost to such entrepreneurial instincts in the country. The Government is all set to provide the requisite support to entrepreneurs by launching various schemes to develop their skills as well as to provide them with the required financial support.

\section{EMERGING OPPORTUNITIES FOR ENTREPRENEURS IN INDIA}

India is realizing the need of developing entrepreneurs in India. The current government, under the leadership of The Honorable Prime Minister Shri Narendra Modi, has taken robust steps towards making India an economic powerhouse by utilizing its demographic dividend. Make in India, Skill India, Digital India, Start-up India are some of the major initiatives by the government that will provide more opportunities to young entrepreneurs and would help in creating more jobs in the country that would ultimately help in the economic growth of the country.

\subsection{START-UP INDIA, STAND-UP INDIA A NEW OPPORTUNITY FOR ENTREPRENEURS}

Start-up India is a new initiative by the government which aims at providing growth opportunities to young entrepreneurs with their new and innovative ideas to start up their own business. This would not only offer an opportunity to young entrepreneurs, but to society at large. People who would get employed through these start-ups would also get new opportunities and better standards of living. This would ultimately lead to the economic growth of the country at large and would also help to solve the problem of unemployment in the country.

The Prime Minister also assured about the financial support to these start-ups by banks. To bring this initiative to reality The Finance Minister, Arun Jaitely, launched two funds by the Small Industries Development Bank of India (Sidbi): India Aspiration Fund for start-ups with the LIC as partner and co-investor, and Sidbi Make in India Loan for Enterprises (SMILE) to provide short term loans and loans in the nature of quasi-equity to small enterprises, as indicated by a report in the Indian Express.

\subsection{ENTREPRENEURSHIP AND SKILL DEVELOPMENT}

Opportunities will likely be created for millions of workers and entrepreneurs by empowering technologies. Up to 20 million small and medium-sized enterprises (SMEs) could gain access to digital business tools in the cloud at a fraction of the cost of running in-house information technology (IT), as stated in a report by McKinsey Global Institute. Star-up India combined with Skill India would give a boost to new entrepreneurs to come up with innovative ideas.

The figure below depicts the sector wise projections for incremental human resource requirement till 2022. The current Indian economy growth is 6.8 percent and is expected to further grow in the coming years. According to Goldman Sachs, India is projected to become the second largest economy in the world by the year 2050 .

It is considered that the Indian economy will thrive on its demographic profile. The current population of India is 1.2 billion and is expected to rise to 1.8 billion by 2045 . This expansion in population is indicative of the fact that there would be increase in the working age (15-64 yrs.) population.

In order to achieve high growth rates with a growing population, skill development has emerged as an important aspect that needs strategic and planned policy cum intervention as indicated by National Skill Development Corporation. The above projections indicate the need for proper skill development programs.

The opportunities that will emerge in different sectors due to "Make in India", "Digital India", and Start-up India" initiatives can only be used if skilled pool of manpower is available with the country. 


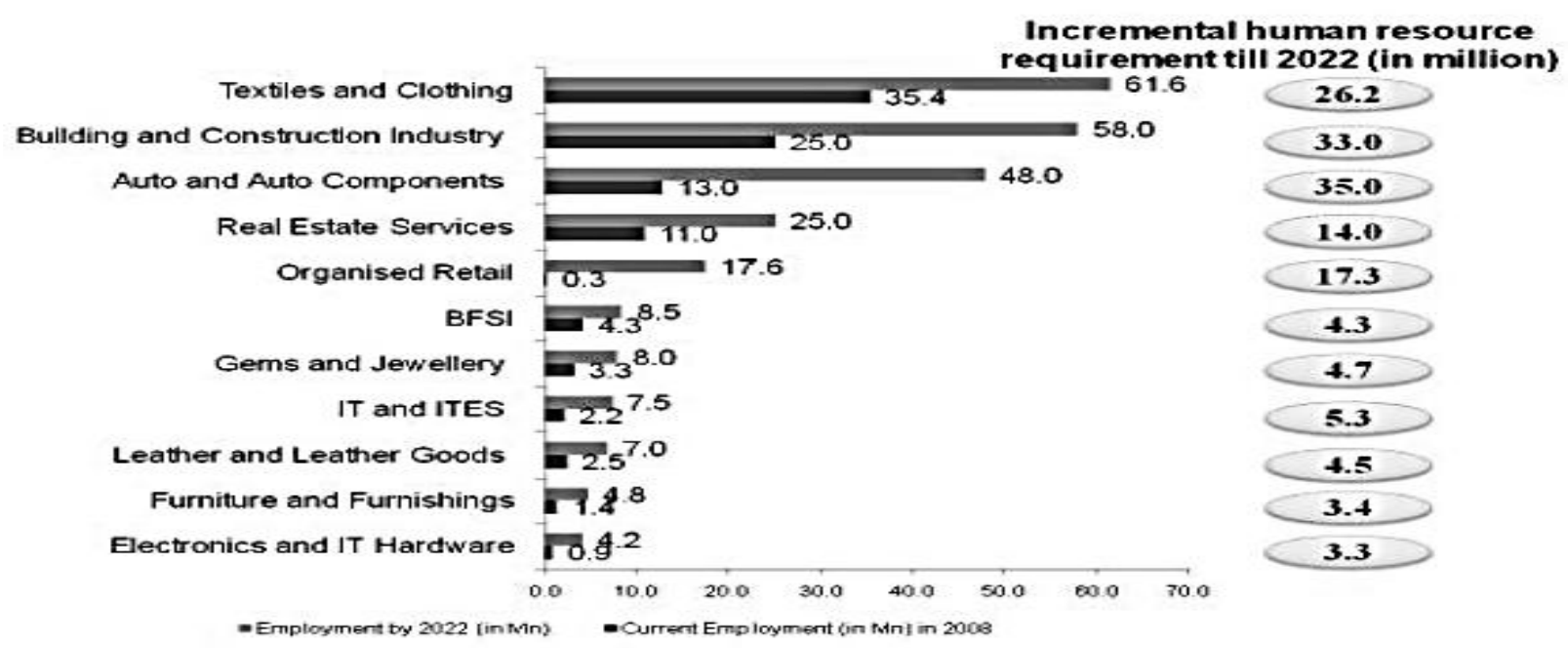

Fig. 4: Source- National Skill Development Corporation

Skill development is a prerequisite to give concrete shape to start-up India. Entrepreneurs can achieve the desired results only when proper skills are imparted to them. Vocational training at various levels is being imparted in India under this initiative. This initiative would impart the required skills in the entrepreneurs and would serve as a motivation factor to the youth to come with their own innovative ideas.

\subsection{Opportunities Available To Entrepreneurs In The Wake Of Digital India}

\subsubsection{Retail Sector}

Constituting about $10 \%$ of its GDP, India's retail sector is emerging as one of the most dynamic and profitable sectors, as stated by Sanjay Kaul, Managing Director - India and SAARC, Cisco. India's retail sector has undergone a great degree of change. Traditional methods of retail trade are being replaced by more smart and digital methods, which include online transactions.

Increased use of internet, smart phones, and other digital devices are giving online retailers new opportunities to tap new markets and increase their market share. Snapdeal, Flipkart, Jabong are some of the leading online retailers that have flourished in the wake of technology driven markets.

Indian e-commerce majorly depends upon Cash-on-Delivery option of payment as 50\% of all online transactions are done in this mode. As per CRISIL report, the online market place holds a mere $18 \%$ while online ticketing has $65 \%$ market share in the 400 billion e-Commerce markets in India (Sanjay Kaul). E-retailers are now trying to venture into rural areas of India. Snapdeal is going to launch 70,000 kiosks in rural India with the help of FINO pay tech (Himanshu Kapania).

This will help the young entrepreneurs in the retail sector to tap the rural markets and increase their market share. It will help the entrepreneurs to grow rapidly and in return will create more job opportunities for the Indian youth, both rural and urban.

\subsubsection{IT sector}

For years, India has been the IT hub for the world and India's IT workers have solved some of the biggest technology problems worldwide. IT gives employment to about 30 lakh people. IT for jobs is an important pillar of the Digital India program. Once Digital India becomes reality, India can give jobs to 5 crore plus people, as indicated by the telecom minister Ravi Shankar Prasad. The digital platform can enable more creative and serviceoriented business models that create employment opportunities. The Digital India project itself will create employment opportunities for 17 million people directly or indirectly which will help in fighting against unemployment problems in India. Government has planned to give IT training to 100 million students in smaller 
towns and villages as employment opportunity in IT sector is very high in India, according to a recent report by Deloitte.

By providing IT training to students, India is on its way to create a skilled pool of young entrepreneurs to tap the emerging opportunities in the wake of digital economy in the coming years. This would help India to achieve its objective of poverty reduction as well as to reduce unemployment levels in the country.

\subsection{MAKE IN INDIA TO PROVIDE A BoOst TO ENTREPRENEURSHIP IN INDIA}

Make in India aims at transforming India into a manufacturing hub and economic powerhouse by eliminating the superfluous laws and regulations, creating more transparent work environment, making bureaucratic processes easier and to take manufacturing growth to $10 \%$ on a sustainable basis. The main objectives of the program are to develop infrastructure, to invite latest technologies and to generate employment opportunities in the country by skill formation.

\section{Major initiatives undertaken}

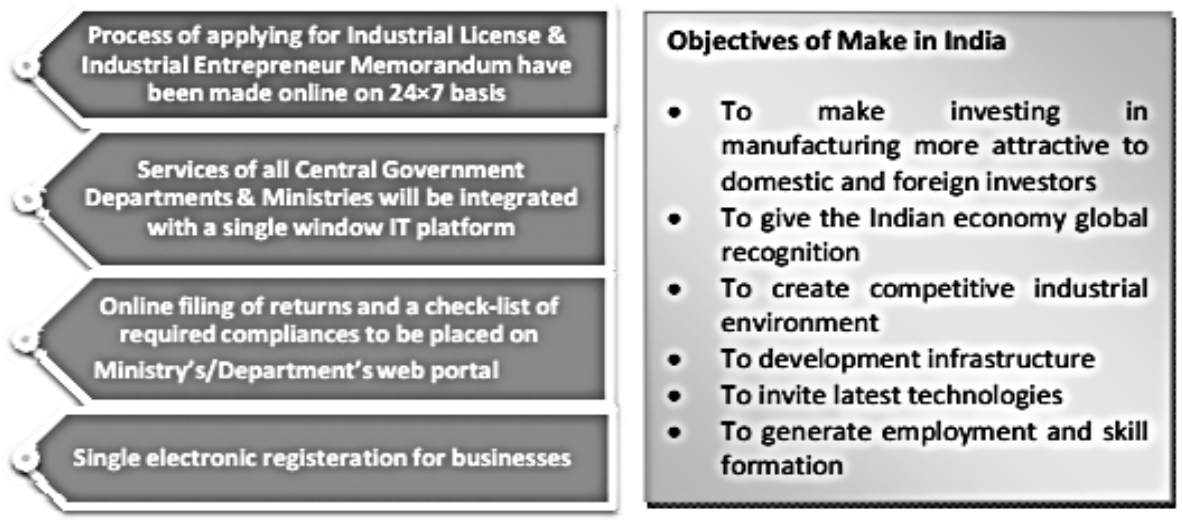

Fig. 5: Major initiatives

Source: PHD Research Bureau

Moreover India has been observing positive sentiments in the previous few months. The figure below represents the Key Macroeconomic Indicators. These indicators represent promising trends in the recent times.

\begin{tabular}{|l|l|c|c|}
\hline S. No. & Parameters & FY14 & H1FY15 \\
\hline 1 & Real GDP Growth & $4.70 \%$ & $5.5 \% \sim$ \\
\hline 2 & WPI Inflation & $6 \%$ & $4.2 \%{ }^{*}$ \\
\hline 3 & CPI Inflation & $9.50 \%$ & $7.4 \%^{*}$ \\
\hline 4 & Industry Growth & $(-) 0.1 \%$ & $1.9 \%^{\star}$ \\
\hline 5 & Exports & $4 \%$ & $4.7 \%^{\star}$ \\
\hline 6 & Fiscal Deficit as \% of GDP & $84.4 \% \wedge$ & $89.6 \%^{\wedge}$ \\
\hline 7 & Current Account Deficit as $\%$ of GDP & $1.70 \%$ & $1.9 \% !$ \\
\hline 8 & FDI Inflows & $8 \%$ & $15 \%$ \\
\hline 9 & Exchange rate & 60.50 & $59.7 \#$ \\
\hline
\end{tabular}

Fig. 6: Key Macroeconomic Indicators

Source: PHD Research Bureau

As already discussed above that India has confidence in its own markets as well as global markets that was represented by a survey conducted by E\&Y in 2015, these positive and encouraging Macroeconomic indicators are 
giving confidence to foreign investors to come to India with their technology and India would provide its skilled workforce to start up the projects.

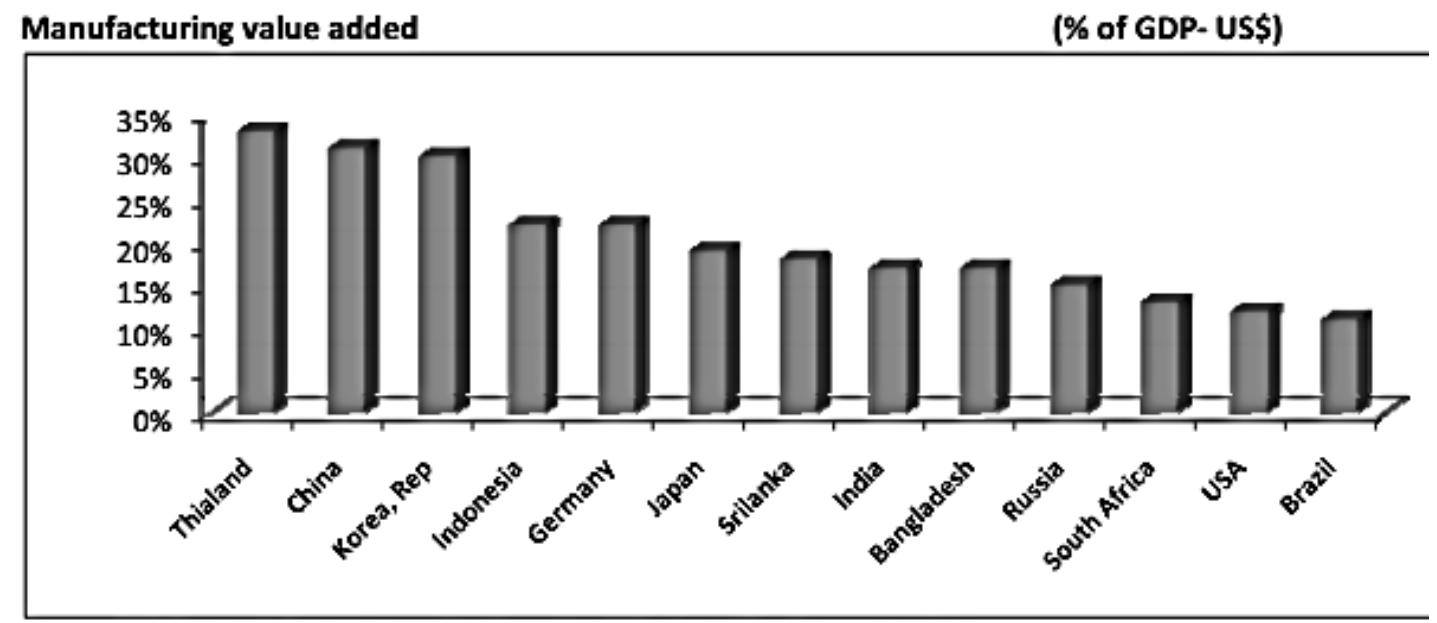

Fig. 7: Source: PHD Research Bureau

Manufacturing sector proves to be the backbone of any economy. India manufacturing sector was a cause of concern especially when other Asian countries, with same development levels, had achieved massive transformation in their manufacturing sectors. The Government immediately focused on this sector after coming to power. To give a boost to the Indian manufacturing sector "Make in India" initiative was taken up by the government. Due to this initiative the growthrate of the manufacturing sector has increased from 5.3\% in 2013-14 to $7.1 \%$ in 2014-15 and 7.2\% in 2015-16 Q1 as indicated by a recent survey by the PHD Research Bureau. All these initiatives will give a boost to the young entrepreneurs as they will get good business and opportunities from the world that would help them as well as the Indian economy to grow and flourish.

\section{Challenges}

Despite of all the initiatives taken by the government to encourage entrepreneurship in India, some major challenges are faced by the government in bringing this dream to reality.

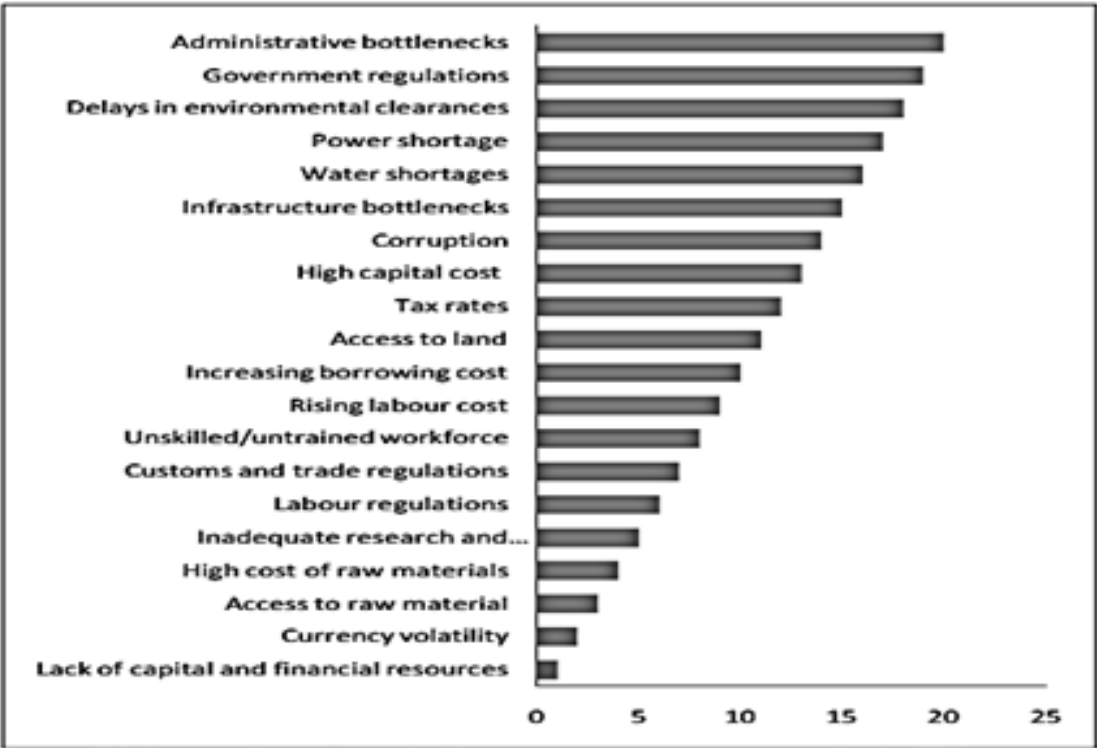

Fig. 8: Rating on Scale of 20on basis of severity (Source: PHD Research Bureau) 
The above figure shows some of the greatest challenges that the government has to deal with, without which all the efforts and initiatives taken up by The Government would go unproductive.

The biggest challenge is to overcome the administrative bottlenecks. These bottlenecks are particularly in case of manufacturing sector. Bureaucratic hurdles, licensing requirements, problems with construction permits, registration of property are some of the administrative bottlenecks faced by the businesses. Without overcoming these bottlenecks The Government would not be in a position to attract foreign collaborations for "Make in India" and the opportunities that would be available due to these foreign collaborations would not be accessible to the entrepreneurs.

Corruption and poor work culture also proves to be major challenge due to which the benefits of the schemes do not reach to the people who need it. It has become imperative to adopt more transparent and responsive attitude to improve the work culture in India. Government has framed certain laws and regulations to achieve this transparency, but India has to go a long way to achieve global standards of conducting work.

Quality of Education also serves as a challenge. Although literacy rates have gone up but the quality of education being imparted is still not satisfactory. Just enrolling students in schools would not serve the purpose until quality education is imparted.

The Government has to overcome all these challenges to achieve its economic as well as social objectives.

\section{CONCLUSION}

The Government has taken major initiatives to achieve its economic objectives. India is very clear about utilizing its demographic dividend to achieve these objectives. Developing and nurturing young entrepreneurs is the major concern of the Government. The rate at which the young population is increasing is not matched with the employment opportunities available in the country. This is the reason due to which government is keen to use the new and innovative ideas of young entrepreneurs to generate more employment opportunities in the country. Many initiatives are taken up by the government in this regard but, before overcoming the challenges it would not be possible for the government to tap its demographic divided.

\section{REFERENCES}

[1] R. Shrivastava, "Role of Entrepreneurship in Economic Development", 2(2), 2013, 1-5.

[2] K. L. Latha and C. Madhavaiah, "Small Scale Entrepreneurship in India, 3(2), 2008, 171-187.

[3] R. C. Ronstadt, "Entrepreneurship Development in India:The Evolution of Entrepreneurship", 1991, 45-61.

[4] S. Fazalbhoy, "Women Entrepreneurship as the Way for Economic Development", 2(1), 2014, $117-127$.

[5] A. Szirmai and W. Naudé and M. Goedhuys, "Development: An Overview", 2010, 3-32.

[6] W. Naudé, "Entrepreneurship and Economic Development: Theory, Evidence and Policy", $2013,7507$.

[7] G. Journal, "Role of Women Entrepreneurs in India", 6(5), 2014, 473-480.

[8] Outreach of microfinance in India. (N.D.), 1-14.

[9] A. K. Tripathi, An overview of entrepreneurship development in India with special, 1-3.

[10] U. Nations and C. On, "United Nations conference on trade and development entrepreneurship and economic development", (May 2004).

[11] P. Braunerhjelm, Entrepreneurship, Innovation and Economic Growth Working Papers Series from Swedish Entrepreneurship Forum.

[12] T. Swetha and K.V. Rao, "Entrepreneurship in India", 2(7), 2013, 104-116.

[13] N. Santhi and S. R. Kumar, "Entrepreneurship Challenges and Opportunities", 1, 2011, 14-16.

[14] E. Prospects and Make India Made India, F. O. R., Exploring prospects for Make in India and Made In India: a study 1, 1-76.

[15] EY global job creation and youth entrepreneurship survey 2015 Boosting employment, inspiring youth, We can work it out. (2015).

[16] Summit, M. (2014). Make In India : Turning Vision Into Reality.

[17] Commission, N. K. (n.d.). UR.

[18] Industry, I. (n.d.). The new wave Indian MSME.

[19] G. H. Full, (2015). Progress of Make in India, (September), 1-44.

[20] Start-Up India plan on Jan 16_ Modi on Mann kiBaat_ The Indian Express. (n.d.). 